\title{
Method for Recovering and Counting Viable Cells from Maize Seeds Inoculated with Azospirillum brasilense
}

\author{
Mariana Sanches Santos ${ }^{1,2}(\mathbb{D})$, Thiago Fernandes Rodrigues ${ }^{1,2}\left(\mathbb{D}\right.$, Eduara Ferreira ${ }^{1}$ (D), \\ Manuel Megias ${ }^{3}$ (D), Marco Antonio Nogueira ${ }^{1}$ (D) and Mariangela Hungria ${ }^{1,2 *}$ (iD \\ ${ }^{1}$ Embrapa Soja, C.P. 231, 86001-970, Londrina, Parana, Brazil. ²Department of Biochemistry and Biotechnology, \\ Universidade Estadual de Londrina, C.P. 60001, 86051-990, Londrina, Parana, Brazil. ${ }^{3}$ Departamento de \\ Microbiologia, Facultad de Biologia, Universidad de Sevilla, C.P. 41012 Seville, Spain.
}

\begin{abstract}
The inoculation of seeds with nitrogen-fixing and plant-growth promoting bacteria is a well-established agricultural practice that has been increasingly adopted worldwide, decreasing costs and environmental impacts of food production. Most of the globally commercialized inoculants are for the soybean crop, and a method for recovery of Bradyrhizobium cells from inoculated soybean seeds for subsequent counting has been adopted by several laboratories of South America, especially to investigate the bacterial survival on seeds treated with pesticides. However, the use of inoculants containing Azospirillum brasilense in cereal crops has exponentially increased, requiring investigation about the recovery and counting of cells from inoculated seeds. We first verified that the method used for recovery and counting of viable cells of Bradyrhizobium from soybean seeds was not applicable for maize seeds inoculated with $A$. brasilense. We then modified several steps of the method, aiming at succeeding in recovering Azospirillum viable cells. The main limitation was identified in the nature of the seed tegument, dry and poor in nutrients, resulting in A. brasilense cell aggregation. Pre-hydration of seeds for $\mathbf{2} \mathrm{h}$ in sterile distilled water, followed by shaking for $\mathbf{3 0} \mathrm{min}$ in sterile distilled water with Tween $\mathbf{8 0}$ allowed proper counting of $A$. brasilense cells recovered from maize seeds. The method was successfully applied to count Azospirillum cells recovered from pre-inoculated maize seeds, and to estimate the impact of seed treatment with pesticides on cell survival.

Keywords: Inoculant, cell recovery, Zea mays, Azospirillum, pesticides
\end{abstract}

\footnotetext{
*Correspondence: mariangela.hungria@embrapa.br; (+55)4333716206
}

(Received: February 18, 2020; accepted: March 19, 2020)

Citation: Mariana Sanches Santos, Thiago Fernandes Rodrigues, Eduara Ferreira, Manuel Megias, Marco Antonio Nogueira and Mariangela Hungria, Method for Recovering and Counting Viable Cells from Maize Seeds Inoculated with Azospirillum brasilense, J. Pure Appl. Microbiol., 2020; 14(1):195-204. https://doi.org/10.22207/JPAM.14.1.21

(C) The Author(s) 2020. Open Access. This article is distributed under the terms of the Creative Commons Attribution 4.0 International License which permits unrestricted use, sharing, distribution, and reproduction in any medium, provided you give appropriate credit to the original author(s) and the source, provide a link to the Creative Commons license, and indicate if changes were made. 


\section{INTRODUCTION}

Concerns about environmental sustainability have resulted in an increasing use of microorganisms in agriculture, aiming at partially or fully replace agrochemicals, with emphasis on fertilizers. Inoculants, also called as biofertilizers in some countries, are products containing living microorganisms that, when applied to the seeds, plant surface, or soil, are able to colonize the rhizosphere or the plants, promoting plant growth by mechanisms such as the biological nitrogen fixation process, or synthesis of phytohormones, improving root growth and increasing nutrient and water uptkae ${ }^{1,3}$.

For more than a century inoculants carrying rhizobia for a variety of legumes have been commercialized worldwide ${ }^{4,5}$. Consequently, methods for counting rhizobial population in soil, inoculants, seeds and plants, as well as for evaluating their symbiotic performance are well established ${ }^{6-8}$. However, particularly in the last two decades, the use of other non-rhizobia plantgrowth promoting bacteria (PGPB) in inoculants has exponentially increased worldwide ${ }^{9}$. Undoubtedly, the most studied and used PGPB belong to the genus Azospirillum, encompassing bacteria with remarkable capacity to benefit a broad range of plant species, mainly by two mechanisms, synthesis of phytohormones and biological nitrogen fixation ${ }^{10-16}$, but that may include a surprisingly number of other biological mechanisms ${ }^{3}$. For example, the synthesis of signals may confer to plants tolerance of abiotic and biotic stresses ${ }^{3}$, and the synthesis of siderophores may help in the protection against plant pathogens ${ }^{1,14,17,18}$.

Nowadays, Brazil and Argentina are the world leaders in the use of inoculants carrying rhizobia and Azospirillum ${ }^{9,12,19}$. In Brazil, Azospirillum has been increasingly used in inoculants for the non-legume crops maize (Zea mays L.) and wheat (Triticum aestivum L.) ${ }^{11}$, pastures of brachiarias (Urochloa spp.) ${ }^{20}$, and also for co-inoculation of the legumes soybean (Glycine max (L.) Merr.) and common bean (Phaseolus vulgaris L.) ${ }^{21,22}$. Noteworthy, the first commercial inoculant with Azospirillum in Brazil was launched in 2009, and reached about 7 million of commercialized doses in the last crop season ${ }^{9}$. About $85 \%$ of the world's agricultural grain production uses pesticides to control a variety of pests and diseases ${ }^{23}$, and one of the main challenges for the success of microbial inoculants is the compatibility with agrochemicals used in seed treatments, especially fungicides and insecticides $s^{4,19,24}$. Low compatibility between rhizobia and pesticides has been long and broadly reported, causing sharp drop in cell survival upon contact with chemicals, decreasing nodulation and yield; therefore, seed treatment with pesticides and inoculants are often incompatible ${ }^{19,24,25}$. However, the use of pesticides for seed treatment continues to increase, representing a threat on the ever-growing increasing use of inoculants, which requires cautious investigation on the compatibility between microbial inoculants and pesticides. Advances in methods for investigating compatibility of rhizobia with pesticides have been achieved and are broadly used in Argentina, Brazil and Uruguay. The main method used in South America was initially developed by Penna et al. $(2011)^{27}$, for the evaluation of Bradyrizobiumfungicides compatibility on soybean seeds. Nowadays, several laboratories from Argentina, Brazil and Uruguay use this method, or slight modifications of it as a quality control procedure for soybean inoculants ${ }^{26-29}$.

Azospirillum may also be affected by pesticides used in seed treatments, and the number of fungicides and pesticides used for the maize crop has increased; for example, more than 30 fungicides are registered for the control of maize diseases in Brazil ${ }^{30}$. However, we found no study reporting the recovery of Azospirillum cells from inoculated seeds of maize. There are well-established methods in the literature for the isolation and identification of endophytic and rhizospheric diazotrophic bacteria in roots, stems and leaves of non-leguminous plants ${ }^{31}$. However, these methods do not meet the objective of this study, which aims to count the number of viable cells surviving on the surface of inoculated seeds. First, we tried to apply the method used for the recovery and counting of Bradyrhizobium from soybean inoculated seeds to the $A$. brasilensemaize combination, trying to verify if this method would be applicable to different plant species and microorganisms. We were surprised to recover zero or close to zero colony forming units (CFU). As the recovery of inoculated cells from seeds is the most accurate way to confirm their ability to 
survive at sowing time, we performed several tests and developed a method to recover Azospirillum viable cells from inoculated maize seeds.

\section{MATERIALS AND METHODS}

\section{Bacterial strains and cultivation methods}

The strains used in this study were Azospirillum brasilense Ab-V5 (=CNPSo 2083) and Ab-V6 (=CNPSo 2084), used in commercial inoculants in Brazil ${ }^{11,29}$. Although the great majority of the commercial inoculants in Brazil carry the two strains, we decided to study them separately, in order to observe if both responded in a similar way. The study also included Bradyrhizobium japonicum strain SEMIA 5079 (=CPAC 15, =CNPSo 07), used in commercial inoculants for the soybean crop in Brazil ${ }^{19}$. The bacteria are deposited at the "Diazotrophic and Plant Growth Promoting Bacteria Culture Collection of Embrapa Soja" (WFCC Collection \# 1213, WDCM Collection \# 1054), in Londrina, State of Parana, Brazil.

For the evaluations, an initial inoculum of each $A$. brasilense strain was obtained in flasks containing $100 \mathrm{~mL}$ of liquid DYGS medium (per liter: glucose, 2 g; malic acid, 2 g; bacto-peptone, $1.5 \mathrm{~g}$; yeast extract, $2 \mathrm{~g} ; \mathrm{K}_{2} \mathrm{HPO}_{4}, 0.5 \mathrm{~g} ; \mathrm{MgSO}_{4} .7 \mathrm{H}_{2} \mathrm{O}$, $0.5 \mathrm{~g}$; glutamic acid, $1.5 \mathrm{~g}$, pH 6.8) ${ }^{32}$ with shaking at $120 \mathrm{rpm}$, at $28^{\circ} \mathrm{C}$, for $24 \mathrm{~h}$. Cell concentration was estimated by reading the optical density (O.D.) at $600 \mathrm{~nm}$, and adjusted to a growth curve previously built establishing the relationship between O.D. and CFU (colony forming units) of each strain. Inocula used in the experiments were always adjusted to a cellular concentration of $10^{8} \mathrm{CFU}$ $\mathrm{mL}^{-1}$ with sterile saline solution $(0.85 \% \mathrm{NaCl})$. For the experiment with B. japonicum, strain SEMIA 5079 was grown in modified-YM (yeast-mannitol) medium $^{33}$.

\section{Cell recovery}

A. brasilense cells recovery from maize seeds inoculated separately with $A$. brasilense strains $A b-V 5$ or Ab-V6 was first performed following the current methodology of cell recovery of Bradyrhizobium spp. from soybean seeds followed by the Brazilian legislation ${ }^{26,29}$, as described $\mathrm{in}^{28}$, but replacing the growth medium for DYGS medium for Azospirillum.

For each strain, $2.5 \mathrm{~mL}$ of each inoculant

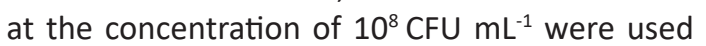
to inoculate $500 \mathrm{~g}$ of maize seeds and left to dry for 2 h. Three biological samples of 100 seeds each were transferred to sterile Erlenmeyer flasks containing $100 \mathrm{~mL}$ of sterile saline solution $(0.85 \%)$ with Tween $80\left(0.4 \mathrm{~mL} \mathrm{~L}^{-1}\right)$. The flasks were submitted to horizontal agitation at 150 rpm for $20 \mathrm{~min}$, resulting in the dilution $10^{\circ}$, that was named as recovery sample. After that, serial dilutions were performed and $100 \mu \mathrm{L}$ aliquot from each dilution and each replicate were spread into a Petri's dish containing RC culture medium (Red Congo $^{34}$ [per liter: malic acid $5 \mathrm{~g} ; \mathrm{K}_{2} \mathrm{HPO}_{4}, 0.5 \mathrm{~g}$; $\mathrm{MgSO}_{4} .7 \mathrm{H}_{2} \mathrm{O}, 0.2 \mathrm{~g} ; \mathrm{NaCl} 0.1 \mathrm{~g}$; yeast extract, $0.5 \mathrm{~g}$; $\mathrm{FeCl}_{3} .6 \mathrm{H}_{2} \mathrm{O}, 0.015 \mathrm{~g}$; $\mathrm{KOH}, 4.8 \mathrm{~g}$; Congo red solution (0.25 g $\left.100 \mathrm{~mL}^{-1}\right), 15 \mathrm{~mL}, \mathrm{pH} 7.0$ ], which permits the recognition of Azospirillum colonies on plates; they form typical red colonies. Seeds may carry several microorganisms, and to decrease the contamination vancomycin $\left(0.1 \mathrm{~g} \mathrm{~L}^{-1}\right)$ was added to the RC medium; the methodology to recover Bradyrhizobium from soybean seeds also includes the same antibiotic at the same concentration ${ }^{29}$. For each biological replicate, three technical replicates were performed. Plates were incubated for 5 days, in the dark, at $28 \pm 2^{\circ} \mathrm{C}$. After this period, the CFU of each plate were evaluated, resulting in zero or close to zero CFU. To try to understand what could have led to this almost zero recovery and knowing that the cell recovery of Bradyrhizobium spp. from soybean seeds based on this methodology is efficient, we chose to inoculate soybean seeds with $A$. brasilense and performed the cell recovery as described above, and once again we were unsuccessful in recovering A. brasilense from the soybean inoculated seeds. From the results obtained in the previous analyses, a new method to evaluate the recovery of Azospirillum from maize seeds was developed. In a first attempt, in order to reduce the stress of Azospirillum during the cell recovery stages, the maize seeds were placed in contact with distilled sterile water for 2 to $4 \mathrm{~h}$ before inoculation. In this procedure, each inoculum was diluted in distilled sterile water (1:2, v:v) prior to seed inoculation, in order to improve the dispersion of bacteria on the surfaces of seeds. The time between inoculation and recovery was reduced from $2 \mathrm{~h}$ to 30 minutes. In addition, we increased the shaking time, from $30 \mathrm{~min}$ to $1 \mathrm{~h}$ during the recovery procedure.

After inoculation of the seeds, the efficacy of cell recovery was analyzed using different 
Table 1. Cellular recovery and cell counting of Azospirillum brasilense from inoculated maize and soybean seeds. Recovery in saline solution with Tween 80

\begin{tabular}{|c|c|c|c|}
\hline \multirow[b]{2}{*}{ Strain } & \multicolumn{2}{|c|}{ Maize seeds } & \multirow{2}{*}{$\begin{array}{c}\text { Soybean seeds } \\
\text { Methodology for } \\
\text { Bradyrhizobium sp. }\end{array}$} \\
\hline & $\begin{array}{l}\text { Methodology for } \\
\text { Bradyrhizobium sp. }\end{array}$ & $\begin{array}{l}\text { H.S. }{ }^{\mathrm{b}} 4 \mathrm{~h} ; 1 \mathrm{~h} \\
\text { shaking }\end{array}$ & \\
\hline A. brasilense Ab-V5 & Very low a & Low $^{\text {a }}$ & Very low a \\
\hline A. brasilense Ab-V6 & Very low ${ }^{a}$ & Low $^{\text {a }}$ & Very low ${ }^{a}$ \\
\hline
\end{tabular}

a Classification based in three biological replicates, each with three technical replicates, as follows: very low recovery: zero or close to zero CFU per $100 \mu \mathrm{L}$ of recovery sample; low recovery: up to $200 \mathrm{CFU}$ per $100 \mu \mathrm{L}$ of sample; very high: $>700 \mathrm{CFU}$ per $100 \mu \mathrm{L}$ of recovery sample; corresponding to very low recovery: zero or close to zero CFU seed ${ }^{-1}$; low recovery: up to $2000 \mathrm{CFU}$ seed $^{-1}$; very high: $>7000$ CFU seed ${ }^{-1}$

${ }^{\mathrm{b}}$ H.S., hydrated seeds in distilled sterile water

diluents in addition to the sterile saline solution (0.85\%), including distilled water and DYGS liquid medium, all three added with Tween 80 (0.4 $\mathrm{mL} \mathrm{L} \mathrm{L}^{-1}$ ). After shaking, a $100 \mu \mathrm{L}$ aliquots of each replicate of the dilutions were spread onto RC solid culture medium, followed by incubation for 5 days, in the dark, at $28 \pm 2{ }^{\circ} \mathrm{C}$. The CFU obtained from each diluent served as parameter to classify the recovery in: very low (zero or close to zero); low (up to $200 \mathrm{CFU}$ per $100 \mu \mathrm{L}$ of recovery sample); medium (between 200 and $500 \mathrm{CFU}$ per $100 \mu \mathrm{L}$ of recovery sample); high (between 500 and 700 CFU per $100 \mu \mathrm{L}$ of recovery sample); and very high (above $700 \mathrm{CFU}$ per $100 \mu \mathrm{L}$ of recovery sample). The choice of levels (200, 500 and 700 CFU) was based on the results obtained.

Following, an analysis was carried out to confirm the efficacy of the developed methodology. For that, $500 \mathrm{~g}$ of maize seeds were treated with $\mathrm{Ab}-\mathrm{V} 5$ or $\mathrm{Ab}-\mathrm{V} 6$ ( $2.5 \mathrm{~mL}$ at the concentration of $10^{8} \mathrm{CFU} \mathrm{mL}$ of diluent), following the developed methodology (Fig. 1). Each treatment was performed in triplicate. Inoculated seeds were maintained under controlled conditions, in the dark, with relative humidity controlled at $50 \pm 5 \%$ and temperature of $25^{\circ} \mathrm{C} \pm 2^{\circ} \mathrm{C}$.

Cell recovery was performed after different times elapsed from inoculation: $2 \mathrm{~h}$ and $1,2,4$ and 15 days of inoculation. A $100 \mu \mathrm{L}$ aliquot of the $10^{\circ}, 10^{-1}, 10^{-2}, 10^{-3}$ and $10^{-4}$ dilutions of each replicate was spread onto RC culture medium in Petri's dishes and after incubation for 5 days, in the dark, at $28^{\circ} \mathrm{C}$ the counting of colony forming units (CFU) was performed.

Finally, we also performed a further experiment with seeds treated with the fungicide
Derosal ${ }^{\circledR}$ Plus (Bayer, composed by carbendazim $250 \mathrm{~g} \mathrm{~L}^{-1}$ and thiram $350 \mathrm{~g} \mathrm{~L}^{-1}$ ), applied as recommended for the maize crop $(40-60 \mathrm{~mL}$ per $20 \mathrm{~kg}$ of seeds) The inoculation procedure and the cell recovery were performed as described in the previous experiment. Cell recovery was performed after $2 \mathrm{~h}$ and $24 \mathrm{~h}$ of inoculation and treatments were: control (inoculated seeds without fungicide) and inoculated seeds treated with fungicides; we did not go beyond $24 \mathrm{~h}$ because cell recovery and counting in the treatment with fungicide was already drastically decreased after $24 \mathrm{~h}$.

\section{Statistical analysis}

Statistical analysis was performed for the quantitative results obtained in the tests of cell recovery and counting in relation to the inoculation time (up to 15 days) and regarding the treatment with pesticide. The data were submitted to the analysis of variance (ANOVA), followed by comparison of means by the Tukey's test at $p<0.05$ with the statistical software Statistica v.12.5.

\section{RESULTS}

Following the current methodology used in South America for cellular recovery of Bradyrhizobium spp. from soybean seeds ${ }^{26-29}, A$. brasilense strains $\mathrm{Ab}-\mathrm{V} 5$ and $\mathrm{Ab}-\mathrm{V} 6$ were single inoculated into maize seeds and submitted to the cell recovery process. Zero or near to zero cells were recovered, being classified in the category of "very low" (Table 1), highlighting that the methodology was not suitable to evaluate the recovery of viable cells of $A$. brasilense from inoculated maize seeds.

In view of the negative results, we decided to inoculate $A$. brasilense on soybean 
Table 2. Cellular recovery and cell counting ${ }^{\mathrm{a}}$ of Azospirillum brasilense from inoculated maize seeds using different diluents

\begin{tabular}{|c|c|c|c|}
\hline Strain & $1 \mathrm{~h}$ agitation & $\begin{array}{l}\text { H.S. }^{b} 4 \mathrm{~h} ; 30 \mathrm{~min} \\
\text { agitation }\end{array}$ & $\begin{array}{l}\text { H.S. } 2 \mathrm{~h} ; 30 \mathrm{~min} \\
\text { agitation }\end{array}$ \\
\hline \multicolumn{4}{|c|}{ Recovery in DYGS medium with Tween 80} \\
\hline Ab-V5 & Medium ${ }^{a}$ & Very high ${ }^{a}$ & Very high ${ }^{\text {a }}$ \\
\hline$A b-V 6$ & High $^{a}$ & Very high a & Very high a \\
\hline \multicolumn{4}{|c|}{ Recovery in water with Tween 80} \\
\hline$A b-V 5$ & Very low a & Very high $^{a}$ & Very high $^{a}$ \\
\hline$A b-V 6$ & Low a & Very high ${ }^{\text {a }}$ & Very high a \\
\hline
\end{tabular}

a Classification based in three biological replicates, each with three technical replicates, as follows: very low recovery: zero or close to zero CFU per $100 \mu \mathrm{L}$ of recovery sample; low recovery: up to $200 \mathrm{CFU}$ per $100 \mu \mathrm{L}$ of recovery sample; medium recovery: between 200 and 500 CFU per 100 hL of recovery sample; high recovery: between 500 and 700 CFU per $100 \mu \mathrm{L}$ of recovery sample; very high: $>700 \mathrm{CFU}$ per $100 \mu \mathrm{L}$ of recovery sample; corresponding to very low recovery: zero or close to zero CFU seed ${ }^{-1}$; low recovery: up to $2000 \mathrm{CFU}_{\text {seed }}{ }^{-1}$; medium recovery: between 2000 and $5000 \mathrm{CFU}_{\text {seed }}{ }^{-1}$; high recovery: between 5000 and $7000 \mathrm{CFU}$ seed $^{-1}$; very high: $>7000 \mathrm{CFU}$ seed $^{-1}$.

${ }^{\mathrm{b}}$ H.S., hydrated seeds in distilled sterile water.

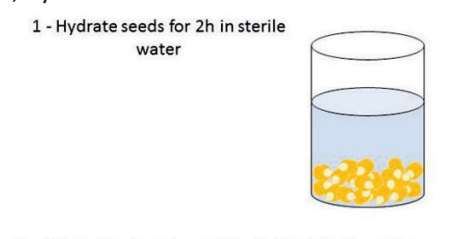

2 - Dilute the inoculum with distilled sterile water $(1: 2, v: v)$. Inoculate the seeds, mix and let dry for $30 \mathrm{~min}$
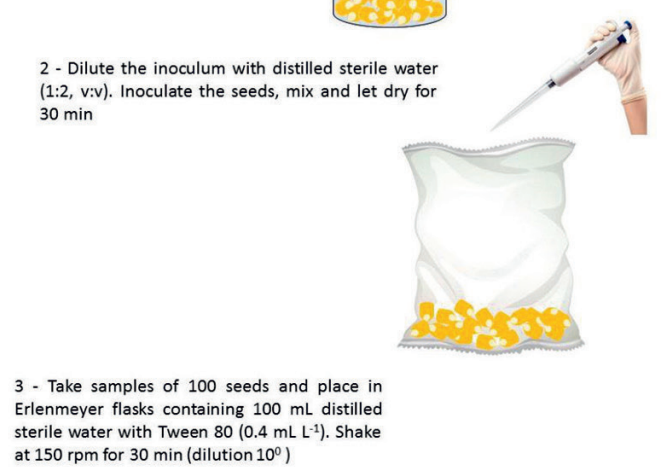

3 - Take samples of 100 seeds and place in Erlenmeyer flasks containing $100 \mathrm{~mL}$ distilled sterile water with Tween $80\left(0.4 \mathrm{~mL} \mathrm{~L}^{-1}\right)$. Shake at $150 \mathrm{rpm}$ for $30 \mathrm{~min}$ (dilution $10^{\circ}$ )

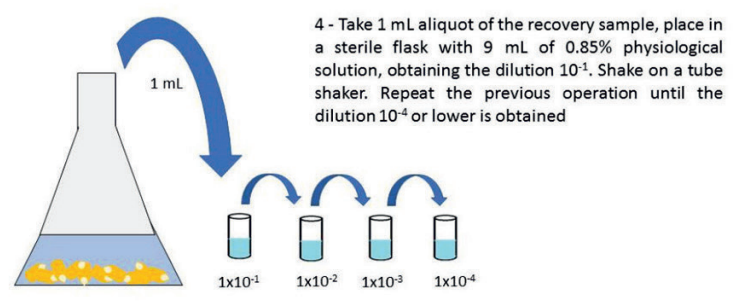

5 - Transfer $100 \mu \mathrm{L}$ of each dilution to Petri dishes containing solid RC medium. Incubate the plates for 5 days at $28^{\circ} \mathrm{C}$

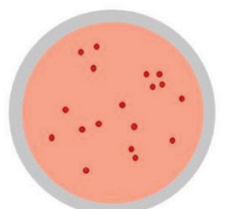

Fig. 1. Schematic outline of the method for estimating the recovery and counting of viable cells of Azospirillum from inoculated maize seeds. 
seeds, as the recovery of Bradyrhizobium in soybean seeds is very successful28. Similar results, with lack of recovery of Azospirillum cells were also obtained in the analysis of soybean seeds inoculated with strains Ab-V5 and Ab-V6 (Table 1 ), whereas high concentration of $B$. japonicum SEMIA 5079 was obtained when the soybean seeds were inoculated with this bacterium, reaching $10^{5}$ to $10^{6} \mathrm{CFU}$ seed ${ }^{-1}$ (data not shown). These results suggested that the inability of $A$. brasilense being recovered by this method was related to specific properties of $A$. brasilense, and not to the maize seed tegument.

As a first modification to try to improve the recovery of $A$. brasilense cells, we verified the effects of hydration of the maize seeds prior to inoculation, the reduction of the time between inoculation and cell recovery, and shaking time. These changes had positive effects on cell recovery (Table 1), but these changes in the methodology were not sufficient to obtain high recovery of cells.

Following, we checked for the efficacy of different diluents in the seed cells recovery phase, comparing saline solution, distilled water, and DYGS medium, all three with Tween $80\left(0.4 \mathrm{~mL} \mathrm{~L}^{-1}\right)$, to verify which one resulted in the highest number of cells in the dilution $10^{\circ}$. Both distilled water and DYGS medium resulted in higher cell recovery and counting, in comparison to the current methodology of recovery of Bradyrhizobium from soybean seeds with saline solution (Tables 1 and 2 ). When the seeds were previously hydrated in distilled water and remained under agitation for $1 \mathrm{~h}$, the recovery ranged between "very low" and "low" when water was used as diluent and between "medium" and "high" when the DYGS medium was used as diluent (Table 2). When the seeds were exposed to hydration for 2 and $4 \mathrm{~h}$ and remained under stirring for 30 minutes, both diluents also resulted in cell recovery and counting classified as "very high".

Based on these results, the following conditions were chosen for $A$. brasilense recovery: seeds previously hydrated in distilled sterile water for $2 \mathrm{~h}$, inoculum diluted in distilled sterile water prior to seed inoculation $(1: 2, \mathrm{v}: \mathrm{v})$, recovery step to the dilution $10^{\circ}$ in water with Tween $80(0.4 \mathrm{~mL}$ $\left.\mathrm{L}^{-1}\right)$, and shaking for $30 \mathrm{~min}$. The subsequent steps, to obtain the following dilutions $\left(10^{-1}, 10^{-2}, 10^{-3}\right.$ and $\left.10^{-4}\right)$, plating of the samples and counting of CFU followed the current methodology for recovery of Bradyrhizobium from soybean seeds ${ }^{26-29}$. The steps can be visualized in Fig. 1.

In order to confirm the efficacy of the developed methodology, we performed the cellular recovery of $A$. brasilense from maize seeds using the new proposed methodology at different times of inoculation ( $2 \mathrm{~h}$ and 1, 2, 4 and 15 days of inoculation). The recovery of Azospirillum viable cells from maize seeds was estimated at $3.84 \mathrm{x}$ $10^{5} \mathrm{CFU}$ seed $^{-1}$ for Ab-V5 and at $5.07 \times 10^{5} \mathrm{CFU}$ seed $^{-1}$ for Ab-V6 with $2 \mathrm{~h}$ of inoculation (Fig. 2). As expected, the number of viable cells recovered from the seeds decreased with time, reaching zero for Ab-V5 and 3.33 CFU seed ${ }^{-1}$ for Ab-V6 after 15 days (Fig. 2). In general, the two strains showed similar behavior, with differences detected only after one day (Fig. 2).

Our last analysis consisted of the recovery of $A$. brasilense Ab-V5 and Ab-V6 strains from maize seeds previously treated or not with fungicide. After $2 \mathrm{~h}$ of inoculation, the concentration of recovered cells from the seeds without fungicideswas (SD in parenthesis) of 1.96 $\times 10^{5} \mathrm{CFU}$ seed $^{-1}\left( \pm 4.1 \times 10^{4}\right)$ for Ab-V5 and $1.55 \times$ $10^{5} \mathrm{CFU} \mathrm{seed}^{-1}\left( \pm 3.63 \times 10^{4}\right)$ for Ab-V6. Cell recovery from seeds previously treated with Derosal ${ }^{\circledR}$ Plus fungicide was $3.37 \times 10^{5} \mathrm{CFU}$ seed $^{-1}\left( \pm 2.11 \times 10^{4}\right)$ for $A b-V 5$, differing significantly from the control, and $5.11 \times 10^{5} \mathrm{CFU}$ seed $^{-1}\left( \pm 2.3 \times 10^{5}\right)$ for Ab-V6. In fungicide-treated seeds the cell concentration

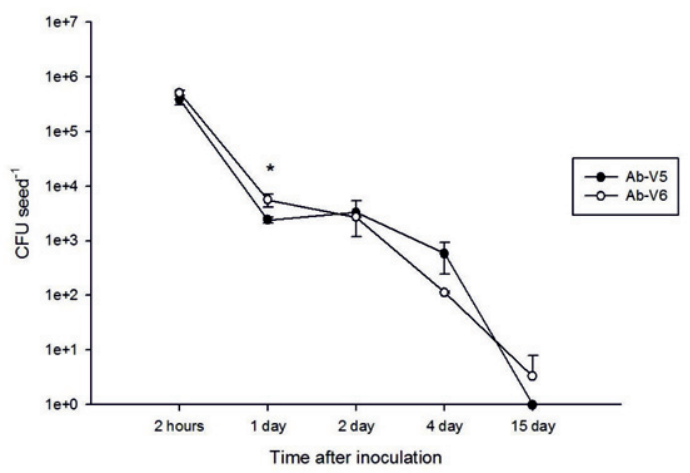

Fig. 2. Concentration of viable cells of Azospirillum brasilense recovered from maize seeds after different periods of inoculation. The data represent the means of three replicates and the bars denote the standard error. $\left({ }^{*}\right)$ treatments that differ from each other by the Tukey's test at $p<0.05$; without $\left({ }^{*}\right)$ indicates that values were not statistically different. 
was drastically reduced with $24 \mathrm{~h}$ of inoculation, reaching zero CFU recovered at dilution $10^{-1}$, whereas in the seeds not treated with fungicides the concentration of recovered cells was of $6.55 x$ $10^{2} \mathrm{CFU} \mathrm{seed}^{-1}\left( \pm 8.31 \times 10^{1}\right)$ for Ab-V5 and of 3.55 $\times 10^{2} \mathrm{CFU}$ seed $^{-1}\left( \pm 9.54 \times 10^{1}\right)$ for Ab-V6.

\section{DISCUSSION}

Brazil, Argentina and Uruguay are well known inoculant consumers, amounting to an inoculant marked nowadays of over 120 million doses year. The method adopted in these countries for the recovery of Bradyrhizobium cells from inoculated soybean seeds has been broadly and successfully used ${ }^{26-29}$. The method is also applicable to other plant-microbe combinations, such as common bean and Rhizobium tropici (data not shown); in addition, dozens of studies, including reports by our group ${ }^{13}$ have successfully recovered Azospirillum and other diazotrophic bacteria from maize rhizosphere, roots and leaves. Therefore, we were surprised for not being able to recover viable cells from maize seeds inoculated with Azospirillum. The same results were obtained when $A$. brasilense was inoculated on soybean seeds, while Bradyrhizobium cells inoculated on soybean seeds had a successful recovery.

In view of all the proven benefits of inoculation of maize seeds with $A$. brasilense described in detail in the literature $\mathrm{e}^{1,3,10,14,15,17,18}$, it is very unlikely that the cells inoculated and not recovered are not viable. Therefore, we believe that the tested methodology was not applicable. As $A$. brasilense is able to colonize the interior of plant tissues ${ }^{14}$, one hypothesis for the almost zero recovery result could be that the bacterium, when in contact with the seed surface, would invade the plant tissue. However, it is not yet known in what situations and how long it would take for A. brasilense cells to leave the seed surface and start invading the cells; in addition, the species establishes preferentially in the rhizosphere.

A well-known feature of $A$. brasilense is its ability to aggregate and flocculate when exposed to various stressing conditions ${ }^{14,35-39}$. Despite several studies showing that the aggregation of A. brasilense increases its tolerance to desiccation and high temperatures $\left(40^{\circ} \mathrm{C}\right)$, positively affecting its survival ${ }^{40,41}$, this represents a serious limitation in studies to verify the survival of Azospirillum on seeds at the sowing time, including the compatibility with pesticides, pre-inoculation, among others.

Therefore, another hypothesis for the unsuccessful recovery was that the contact of $A$. brasilense with seeds, a dry and nutritionally poor surface, would result in bacteria aggregation/ flocculation. Consequently, when inoculated in solidified culture medium, each cell aggregate, containing hundreds of cells, would result in only one CFU, underestimating the number of CFU $\operatorname{seed}^{-1}$. Based on this hypothesis, alternatives were investigated to reduce the stressing conditions. First, we investigated the effect of seed hydration with sterile distilled water for up to $4 \mathrm{~h}$ before inoculation, as well as the effect of increasing the shaking time. When maize seeds were hydrated prior to inoculation, the conditions were less stressful to the bacteria, reducing the cell aggregation/flocculation, and resulting in satisfactory recovery, while increasing the shaking time from $30 \mathrm{~min}$ to $1 \mathrm{~h}$ did not impact the recovery of both strains (Tables 1 and 2). It is important to consider that this is a methodology for laboratory analysis of the quality of inoculants, so the seeds used for this purpose would not be taken to the field by farmers. One may also consider that the absorption kinetics of the inoculant might be affected by the pre-treatment. However, the volume used was considerably lower than that usually employed by the farmers in liquid products used for seed treatment and, in addition, in our methodology we investigated the minimum volume needed to allow cell recovery and counting.

In this new methodology of recovering cells of Azospirillum from inoculated seeds, the first step consists in effectively removing the inoculated bacteria from the seeds and to transfer them to an aqueous medium for further analysis of cell counting. Saline solution $(\mathrm{NaCl} 0.85 \%)$ is used as a diluent in most of the microbiological techniques, acting on the osmotic balance between inside the cell and the external environment. However, as the methodology using saline solution failed, we proceeded to a second modification that consisted in replacing the saline solution by different diluents, including distilled water and DYGS medium, always with Tween 80 . The two new diluents positively influenced the bacterial 
cellular recovery from the seeds and cell counting. Considering these results, we hypothesized that the saline solution would also contribute to the cellular aggregation/flocculation, interfering in the final counting of CFU. As both distilled water and DYGS medium presented similar results, we opted by distilled water with Tween 80 , due to the low cost and easy preparation compared to the DYGS medium. Therefore, we may conclude that by hydrating the seeds before inoculation and by using distilled water with Tween 80 as a diluent for cell recovery, the stressing conditions for Azospirillum will be reduced, decreasing aggregation/flocculation and allowing proper cell recovery and counting.

In general, quality control of microbial inoculants is based on cell concentration and absence of contaminants. Great progresses have been achieved at the industry, with the development of products with high concentration of cells, while legal or private control of the concentration guarantees that the farmers will receive appropriate products ${ }^{4,8,19,42,43}$. However, even more important than inoculant concentration is to know how many cells are alive on the inoculated seeds at sowing. In this context, the proposed method is of great relevance for the evaluation of the efficacy of inoculation of maize seeds, because it allows to know the cellular concentration of $A$. brasilense in each inoculated seed. This information is very important and our results for cell recovery after inoculation and in seeds treated with fungicides show that it is useful in several studies, such as the development of new inoculant formulations, verification of compatibility between pesticides and inoculants, viability of pre-inoculation, among others, and may also help to guide policies of recommendation of microbial inoculants, so that the farmers will benefit from the best technologies.

\section{CONCLUSION}

A methodology was developed to evaluate the recovery and counting of Azospirillum viable cells from inoculated maize seeds (Fig. 1). The methodology was successful to recover and count viable cells of $A$. brasilense from maize seeds after different times of inoculation, as well as to verify the effects of pesticides on Azospirillum survival on the seeds, and may as well be applied to several other studies related to inoculants and inoculation.

\section{AUTHORS' CONTRIBUTIONS}

Conceived and designed the experiments: MSS, MM, MH, Performed the experiments: MSS, TFR, EF. Analyzed the data: MSS, TFR, EF. $\mathrm{MM}, \mathrm{MAN}, \mathrm{MH}$. Contributed reagents/materials/ analysis tools: MAN, MH. Wrote the paper: MSS, TFR, EF, MM, MAN, MH

All authors read and approved the final manuscript.

\section{ACKNOWLEDGEMENTS}

MS Santos acknowledges a PhD fellowship from Araucaria Foundation of support to the Scientific and Technological Development of the State of Parana and T.F. Rodrigues acknowledges an MSc fellowship from CAPES (Coordenanto de Aperfeinoamento de Pessoal de Novel Superior - Brasil - Finance Code 001). M.A. Nogueira and M. Hungria are also research fellows from $\mathrm{CNPq}$ (Brazilian National Research Council for Science and Technology).

\section{CONFLICT OF INTEREST}

The authors declare that there is no conflict of interest.

\section{FUNDING}

Funded by INCT-Plant-Growth Promoting Microorganisms for Agricultural Sustainability and Environmental Responsibility (CNPq 465133/20142, Fundanto Araucaria-STI, CAPES), Embrapa, CNPq-Universal (400468/2016-6).

\section{ETHICS STATEMENT}

This article does not contain any studies with human participants or animals performed by any of the authors.

\section{DATA AVAILABILITY}

All datasets generated or analyzed during this study are included in the manuscript, and complementary dataset will be available upon request to the corresponding author

\section{REFERENCES}

1. Bhattacharyya PN, Jha DK. Plant growth-promoting rhizobacteria (PGPR): emergence in agriculture. World 
J Microbiol Biotechnol, 2012; 28: 1327-1350. https:// doi.org/10.1007/s11274-011-0979-9.

2. Malusa E, Vassilev N. A contribution to set a legal framework for biofertilisers. Appl Microbiol Biotechnol, 2014; 98: 6599-6607. https://doi.org/10.1007/ s00253-014-5828-y.

3. Fukami J, Cerezin P, Hungria M. Azospirillum: benefits that go far beyond biological nitrogen fixation. $A M B$ Express, 2018; 8: 1-12. https://doi.org/10.1186/ s13568-018-0608-1.

4. Hungria M, Loureiro MF, Mendes IC, Campo RJ, Graham PH. 2005. Inoculant preparation, production and application, pp. 223-254. In Newton WE (ed.), Nitrogen fixation: origins, applications and research progress. Dordrecht, Springer. https://doi.org/10.1007/1-40203544- 6_11.

5. Ormeno-Orrillo E, Hungria M, Martinez-Romero E. 2013. Dinitrogen-fixing prokaryotes, pp.427-451. In Rosemberg E, De Long EF, Lory S, Stackebrandt E, Thompson $F$ (eds.), The Prokaryotes - prokaryotic physiology and biochemistry. Berlin Heidelberg, Springer-Verlag. <https://doi.org/10.1007/978-3-64230141-4_72>.

6. Yates $M \bar{G}$. 1980. Methods for evaluating biological nitrogen fixation, pp 480. In Bergersen FJ (ed.), Biochem Soc Transact, John Wiley \& Sons, Chichester. https:// doi.org/10.1042/bst0090482.

7. Hungria M, Araujo RS. Manual de metodos empregados em estudos de Microbiologia Agricola, 1994; pp. 542. EMBRAPA-SPI, Brasilia. https://doi.org/10.13140/ RG.2.1.2663.4727.

8. Howieson JG, Dilworth MJ. Working with rhizobia, 2016; pp. 312. Australian Center for International Agricultural Research (ACIAR), Canberra, Australia. ISBN 9781925436181.

9. Santos MS, Nogueira MA, Hungria M. Microbial inoculants: reviewing the past and previewing an outstanding future for the use beneficial bacteria in agriculture. AMB Express, 2019; 9: 1-22. https://doi. org/10.1186/s13568-019-0932-0.

10. Bashan Y, De-Bashan LE. 2010. How the plant growth promoting bacterium Azospirillum promotes plant growth - a critical assessment, pp. 77-136. In Donald LS, (ed.), Advances in Agronomy. Academic Press, Delaware. https://doi.org/10.1016/S00652113(10)08002-8.

11. Hungria M, Campo RJ, Souza EM, Pedrosa FO. Inoculation with selected strains of Azospirillum brasilense and $A$. lipoferum improves yields of maize and wheat in Brazil. Plant Soil, 2010; 331: 413-425. https://doi.org/10.1007/s11104-009-0262-0.

12. Okon Y, Labandera-Gonzales C, Lage M, Lage P. 2015. Agronomic applications of Azospirillum and other PGPR, pp.921-932. In De Bruijn FJ (ed.), Biological nitrogen fixation. Hoboken, New Jersey. https://doi. org/10.1002/9781119053095.ch90.

13. Fukami J, Nogueira MA, Araujo RS, Hungria M. Accessing inoculation methods of maize and wheat with Azospirillum brasilense. AMB Express, 2016; 6: 1-13. https://doi.org/10.1186/s13568-015-0171-y.

14. Pereg L. 2015. Azospirillum cell aggregation, attachment and plant interaction, pp. 181-197. In
Cassan FD, Okon Y, Creus CM (eds.), Handbook for Azospirillum: Technical Issues and Protocols. Cham., Springer International Publishing. <https://doi. org/10.1007/978- 3-319-06542-7>.

15. Pereg L, de-Bashan LE, Bashan Y. Assessment of affinity and specificity of Azospirillum for plants. Plant Soil, 2016; 399: 389-414. https://doi.org/10.1007/s11104015-2778-9.

16. Dutta S, Podile AR. Plant growth promoting rhizobacteria (PGPR): the bugs to debug the root zone. Crit Rev Microbiol, 2010; 36: 232-244. https:// doi.org/10.3109/10408411003766806

17. Tortora ML, Diaz-Ricci JC, Pedraza RO. Azospirillum brasilense siderophores with antifungal activity against Colletotrichum acutatum. Arch Microbiol, 2011; 193: 275-286. https://doi.org/10.1007/s00203-010-06727.

18. Lopez-Reyes L, Carcano-Montiel MG, Lilia T-L, Medinade la Rosa G, Armando T-HR. Antifungal and growthpromoting activity of Azospirillum brasilense in Zea mays L. ssp. mexicana. Arch. Phytopathology Plant Protect 2017; 50: 727-743. https://doi.org/10.1080/ 03235408.2017.1372247.

19. Hungria M, Mendes IC. 2015. Nitrogen fixation with soybean: the perfect symbiosis?, pp. 1009-1023. In De Bruijn FJ (ed.), Biological nitrogen fixation. Hoboken, New Jersey. https://doi.org/0.1002/9781119053095. ch99.

20. Hungria M, Nogueira MA, Araujo RS. Inoculation of Brachiaria spp. with the plant growth-promoting bacterium Azospirillum brasilense: an environmentfriendly component in the reclamation of degraded pastures in the tropics. Agric Ecosyst Environ, 2016; 221: 125-131. https://doi.org/10.1016/j. agee.2016.01.024.

21. Hungria M, Nogueira M, Araujo R. Co-inoculation of soybeans and common beans with rhizobia and azospirilla: strategies to improve sustainability. Biol Fertil Soils 2013; 49: 791-801. https://doi. org/10.1007/s00374-012-0771-5.

22. Hungria M, Nogueira MA, Araujo RS. Soybean seed coinoculation with Bradyrhizobium spp. and Azospirillum brasilense: A new biotechnological tool to improve yield and sustainability. Amer J Plant Sci, 2015; 6: 81181715. https://doi.org/10.4236/ajps.2015.66087.

23. Kim K-H, Kabir E, Jahan SA. Exposure to pesticides and the associated human health effects. Sci Total Environ 2017; 575: 525-535. https://doi.org/10.1016/j. scitotenv.2016.09.009.

24. Campo RJ, Araujo RS, Hungria M. Nitrogen fixation with the soybean crop in Brazil: Compatibility between seed treatment with fungicides and bradyrhizobial inoculants. Symbiosis, 2009; 48: 154-163. https://doi. org/10.1007/BF03179994.

25. Elslahi RH, Osman AG, Sherif AM, Elhussein AA. Comparative study of the fungicide Benomyl toxicity on some plant growth promoting bacteria and some fungi in pure cultures. Interdiscip Toxicol, 2014; 7: 12-16. https://doi.org/10.2478/intox-2014-0002.

26. Campo RJ, Hungria M. Anais da XIII Reuniao da Rede de Laboratorios para Recomendacao, Padronizacao e Difusao de Tecnologia de Inoculantes Microbianos 
de Interesse Agricola (RELARE). Embrapa Soja, Londrina, pp. 212 (Embrapa Soja. Documentos, 290), 2007. ISSN 1516-781X. https://ainfo.cnptia. embrapa.br/digital/bitstream/item/82266/1/ Anais-da-XIII-Reuniao-da-Rede-de-Laboratoriospara-Recomendacao-Padronizacao-e-Difusao-deTecnologia-de-Inoculantes-Microbianos-de-InteresseAgricola-RELARE.pdf.

27. Penna C, Massa R, Olivieri F, Gutkimd G, Cassan FD. A simple method to evaluate the number of bradyrhizobia on soybean seeds and its implication on inoculant quality control. AMB Express, 2011; 1: 21. https://doi.org/10.1186/2191-0855-1-21.

28. Araujo RS, da Cruz SR, Souchie EL, Martin TN, Nakatani AS, Nogueira MA, Hungria M. Pre-inoculation of soybean seeds treated with agrochemicals up to 30 days before sowing: Technological innovation for large-scale agriculture. Int J Microbiol, 2017; 2017: 1-11. https://doi.org/10.1155/2017/5914786.

29. MAPA - Ministerio da Agricultura, Pecuaria e Abastecimento. Instrucao Normativa no. 30, 12/11/2010. http://www.agricultura.gov.br/ assuntos/insumos-agropecuarios/insumos-agricolas/ fertilizantes/legislacao/in-30-2010-dou-17-11-10metodo-inoculantes.pdf.

30. Cota LV, Costa RV, Sabato EO, Silva DD. Historico e perspectivas das doencas na cultura do milho. Embrapa Milho e Sorgo, Sete Lagoas, pp. 7 (Embrapa Circular Tecnica, n. 193) 2013. https://www.embrapa. br/busca-de-publicacoes/-/publicacao/975363/ historico-e-perspectivas-das-doencas-na-cultura-domilho.

31. Baldani JI, Reis VM, Videira SS, Boddey LH, Baldani VLD. The art of isolating nitrogen-fixing bacteria from non-leguminous plants using $\mathrm{N}$-free semi-solid media: a practical guide for microbiologists. Plant Soil, 2014; 384: 413-431. https://doi.org/10.1007/s11104-0142186-6.

32. Fukami J, Abrantes JLF, del Cerro P, Nogueira MA, Ollero $\mathrm{FJ}$, Megias M, Hungria M. Revealing different strategies of quorum sensing in Azospirillum brasilense strains Ab-V5 and Ab-V6. Arch Microbiol, 2018; 200: 47-56. https://doi.org/10.1007/s00203-017-1422-x.

33. Hungria M, O'Hara GW, Zilli JE, Araujo RS, Deaker R, Howieson JG. 2016. Isolation and growth of rhizobia, pp. 39-60. In Howieson JG, Dilworth MJ (eds.), Working with rhizobia, Canberra, Australia, ACIAR.
34. Caceres EAR. Improved medium for isolation of Azospirillum spp. Appl Environ Microbiol, 1982; 44: 990-991.

35. Madi L, Kessel M, Sadovnik E, Henis Y. Electron microscopic studies of aggregation and pellicle formation in Azospirillum spp. Plant Soil, 1988; 109: 115-121. https://doi.org/10.1007/BF02197588.

36. Burdman S, Jurkevitch E, Schwartsburd B, Hampel M, Okon Y. Aggregation in Azospirillum brasilense: effects of chemical and physical factors and involvement of extracellular components. Microbiology, 1998; 144: 1989-1999. https://doi.org/10.1099/00221287-1447-1989.

37. Burdman S, Okon Y, Jurkevitch E. Surface characteristics of Azospirillum brasilense in relation to cell aggregation and attachment to plant roots. Critical Rev Microbiol, 2000; 26: 91-110. https://doi. org/10.1080/10408410091154200.

38. Bahat-Samet E, Castro-Sowinski S, Okon Y. Arabinose content of extracellular polysaccharide plays a role in cell aggregation of Azospirillum brasilense. FEMS Microbiol Lett, 2004; 237: 195-20. https://doi. org/10.1016/j.femsle.2004.06.036.

39. Santos MS, Hungria M, Nogueira A. Production of $\mathrm{PHB}$ and biofilm by Azospirillum brasilense aiming at the development of liquid inoculants with high performance. Afr J Biotechnol, 2017; 16: 1855-1862. https://doi.org/10.5897/AJB2017.16162.

40. Vendan RT, Thangaraju M. Development and standardization of liquid formulation for Azospirillum bioinoculant. Indian J Microbiol, 2006; 46: 379-387. https://doi.org/10.1556/AMicr.54.2007.2.7.

41. Joe MM, Jaleel CA, Sivakumar PK, Zhao C, Karthikeyan B. Coaggregation in Azospirillum brasilense MTCC-125 with other PGPR strains: Effect of physical and chemical factors and stress endurance ability. J Taiwan Inst Chem Eng, 2009; 40: 491-499. https://doi.org/10.1016/j. jtice.2009.02.00.

42. Lupwayi NZ, Olsen PE, Sande ES, Keyser HH, Collins MM, Singleton PW, Rice WA. Inoculant quality and its evaluation. Field Crops Res, 2000; 65: 259-270. https:// doi.org/10.1016/S0378-4290(99)00091-X.

43. Herridge DF, Hartley E, Gemell LG. Rhizobial counts in peat inoculants vary amongst legume inoculant groups at manufacture and with storage: Implications for quality standards. Plant Soil, 2014; 380: 327-336. https://doi.org/10.1007/s11104-014-2087-8. 